\title{
INFERTILITY AND SEXUAL DYSFUNCTIONS: A SYSTEMATIC LITERATURE REVIEW
}

\author{
Andrej Starc ${ }^{1}$, Manca Trampuš², Doroteja Pavan Jukić ${ }^{3}$, Cecilija Rotim ${ }^{4}$, \\ Tomislav Jukić 5 and Ana Polona Mivšek ${ }^{6}$
}
${ }^{1}$ Department of Public Health, Faculty of Health Sciences, University of Ljubljana, Ljubljana, Slovenia;
${ }^{2}$ Jesenice General Hospital, Department of Pediatrics, Jesenice, Slovenia;
${ }^{3}$ Department of Gynecology and Obstetrics, Faculty of Medicine, Josip Juraj Strossmayer
University of Osijek, Osijek, Croatia;
${ }^{4}$ Dr Andrija Štampar Teaching Institute of Public Health, Zagreb, Croatia;
${ }^{5}$ Department of Internal Medicine, Family Medicine and History of Medicine, Faculty of Medicine, Josip Juraj Strossmayer University of Osijek, Osijek, Croatia;
${ }^{6}$ Department of Midwifery, Faculty of Health Sciences, University of Ljubljana, Ljubljana, Slovenia

SUMMARY - This study aimed to investigate whether infertility and its treatment affect couple sexuality. A systematic literature review was performed, focusing on female and male sexual dysfunctions due to infertility. The method was descriptive, using a meta-synthesis of scientific research published between 2012 and 2017 in the English language. The search for suitable studies was carried out with the research databases Medline, CINAHL, PubMed and ScienceDirect using the following keywords: infertility, sexual dysfunctions, couple. It can be concluded that infertility negatively affects the sexuality of an infertile couple, which is further proven by a high percentage of sexual dysfunctions (43\%-90\% among women and 48\%-58\% among men). Couples report less satisfaction with sexuality. Since lower satisfaction and dysfunctions are closely connected with infertility and its treatment, couples might benefit from sexual therapy and support during the process of infertility treatment. Further research should focus on the evaluation of different psychological interventions that would address sexuality in couples when diagnosed and treated for infertility.

Key words: Infertility; Sexuality; Erectile dysfunction; Sexual dysfunctions, psychological

\section{Introduction}

Fertility in women is said to be at the highest level during their twenties and thirties, while in men fertility remains high until their forties. Conception in healthy fertile couples happens on average after 8 months of regular intercourse ${ }^{1}$. Infertility is defined as the inability to conceive after a year of regular unprotected sexual activity ${ }^{2}$. Globally, the fertility rate is de-

Correspondence to: Asst. Prof. Andrej Starc, PhD, Faculty of Health Sciences, Department of Public Health, University of Ljubljana, Zdravstvena pot 5, 1000 Ljubljana, Slovenia

E-mail: andrej.starc@guest.arnes.si

Received June 13, 2018, accepted July 24, 2018 clining, due to several different factors, especially environmental changes ${ }^{3}$.

A study on global infertility rates, performed from 1990 to 2010 in 190 countries, revealed 48.5 million infertile couples of which 19.2 million suffered from primary infertility, while 29.3 million were diagnosed with secondary infertility. The research results showed that couples in developed countries more often suffered from primary infertility, whereas in developing countries secondary infertility was more common ${ }^{4}$.

The reasons for infertility can be found in women or in men, sometimes even in both. The female reproductive function can be impaired by the innate or acquired circumstances that affect the normal function 
of reproductive organs (genital etiology), illnesses (extragenital etiology), or by psychological factors ${ }^{5,6}$. For male infertility, three possible categories of reasons exist, i.e. unobstructive etiology (where the problem is the production of sperm), obstructive etiology (where the problem is transportation of the sperm through the genital tract), while coital infertility is caused by disorders that hinder erection and ejaculation. Commonly, there are joint causes of male and female factors for the couple's infertility. In $10 \%-15 \%$ of cases, the etiology of infertility remains idiopathic infertility ${ }^{1,7}$.

Infertility affects different areas of the couple's life. Unsuccessful family planning has a negative impact on individual's feelings, and many couples describe the period of diagnosis and treatment of infertility as the most stressful period of their life ${ }^{8}$. The ability of reproduction is closely connected with self-image, self-respect, and sexuality. Sexual intercourse may lose its spontaneity and erotic value because the main aim becomes conception. This may affect the ability for intimate sexuality and can provoke certain sexual dysfunctions ${ }^{8,9}$. The treatment of infertility dictates the frequency and timing of sexual intercourse; the usual intimate event becomes regulated, controlled and couples often sense that the medical team is symbolically present also during their most personal act ${ }^{10}$. Problems often occur due to the emotional impact of the diagnosis, and forced and dictated sexual relations as part of the treatment and management of the problem ${ }^{11}$.

Sexual dysfunctions can appear in both partners and might provoke problems in every stage of sexual response ${ }^{12}$. Sexual dysfunctions can be a reason for infertility or can be triggered by infertility ${ }^{8}$. The classification of male and female sexual dysfunctions by the American Psychiatric Association ${ }^{13}$ is presented in Table 1.

The Diagnostic and Statistical Manual of Mental Disorders does not provide the possibility of a special diagnosis for sexual dysfunctions due to infertility. The diagnoses of female sexual arousal disorder and hypoactive sexual desire disorder are used, and a medical condition (infertility) can be used as a differential diagnosis; the criterion for diagnosis is that the duration of problems is more than six months. The therapist must be aware that additional diagnoses (sexual problems) can further damage the self-esteem of infertile patients. The treatment utilizes a cognitive behavioral
Table 1. Classification of male and female sexual disorders by the American Psychiatric Association 2013

\begin{tabular}{|c|c|c|}
\hline $\begin{array}{l}\text { Type of } \\
\text { disorder }\end{array}$ & Men & Women \\
\hline Desire & $\begin{array}{l}\text { Male hypoactive } \\
\text { sexual desire } \\
\text { disorders }\end{array}$ & $\begin{array}{l}\text { Female sexual } \\
\text { interest/arousal } \\
\text { disorder }\end{array}$ \\
\hline Arousal & Erectile disorder & $\begin{array}{l}\text { Female sexual arousal } \\
\text { disorder }\end{array}$ \\
\hline Orgasm & $\begin{array}{l}\text { Delayed ejaculation, } \\
\text { premature (early) } \\
\text { ejaculation }\end{array}$ & $\begin{array}{l}\text { Female orgasmic } \\
\text { disorder, anorgasmia }\end{array}$ \\
\hline Pain & $\begin{array}{l}\text { Penodynia, } \\
\text { scrotodynia }\end{array}$ & $\begin{array}{l}\text { Genito-pelvic pain } \\
\text { /penetration disorder } \\
\text { vaginismus }\end{array}$ \\
\hline
\end{tabular}

approach, an intervention that improves marital and sexual satisfaction. The main strategies of treatment are directed to lessen the anxiety, to improve the ability to reach orgasm, intimacy, and communication; in addition, the main goal is to break beliefs tied to fertility that can negatively affect the couple's sexuality (for example, that a woman's worth is connected to her fertility, and that masculinity is defined by the ability to perform sexually). Piva et al. ${ }^{9}$ argue that this could be useful to prepare couples entering infertility treatment for possible obstacles in sexuality.

In a study that included 121 women diagnosed with infertility, researchers identified a $26 \%$ prevalence of sexual dysfunctions, while in a subsequent study experts found an even higher proportion of sexual problems $(61.7 \%)^{14,15}$. A systematic literature review concluded that women faced sexual disorders more often than men when dealing with infertility ${ }^{16}$.

\section{Objectives}

This study aimed to perform a systematic literature review regarding the impact of infertility on sexual disorders in couples. The main research questions were:

- how the infertility treatment affects sexuality of the couple;

- how often infertile couples face sexual dysfunctions; and

- how infertility affects perceptions of sexual satisfaction in the couple? 


\section{Methods}

A systematic search of medical databases was performed. Medline, CINAHL, PubMed and ScienceDi-

Table 2. Categorization of evidence (Eccles and Mason, 2001) 17

\begin{tabular}{|c|c|}
\hline Category & Methodological strength of evidence \\
\hline $\mathrm{I}$ & $\begin{array}{l}\text { Meta-analysis of randomized controlled } \\
\text { trials (RCT) or at least one RCT }\end{array}$ \\
\hline II & $\begin{array}{l}\text { A controlled study (non-randomized), } \\
\text { other type of quasi-experimental study }\end{array}$ \\
\hline III & $\begin{array}{l}\text { Nonexperimental descriptive studies, such } \\
\text { as comparative studies, correlation studies, } \\
\text { and case control studies }\end{array}$ \\
\hline IV & $\begin{array}{l}\text { Evidence from expert committee reports } \\
\text { or opinions and/or clinical experience of } \\
\text { respected authorities }\end{array}$ \\
\hline
\end{tabular}

rect were searched with the following keywords: infertility, couple, sexuality, dysfunction. The search was performed in April 2017. Inclusion criteria were studies published in the previous five years; studies published in the English language; and studies focused on the research of sexual function of infertile individuals.

Sixteen studies were identified as appropriate for analysis. They were categorized by methodological quality using Eccles-Mason categorization ${ }^{17}$. Studies rated in category I have the strongest and those in category IV the least methodological quality, as shown in Table 2.

All 16 studies were categorized as belonging in category II.Meta-analysis of the studies enabled in-depth analysis of the contents and generalization of the newest, empirically sound results to address research questions set in the purpose of the study.

Table 3. Research findings regarding the effect of infertility on couple sexuality

\begin{tabular}{|c|c|c|}
\hline Authors (year) & Description of methodology & Summary of results \\
\hline $\begin{array}{l}\text { Marci et al. } \\
(2012)^{18}\end{array}$ & $\begin{array}{l}30 \text { couples diagnosed with infertility in the } \\
\text { previous two months, } 30 \text { primary infertile } \\
\text { couples in the process of infertility treatment } \\
\text { and } 52 \text { fertile. The research aimed to define } \\
\text { whether personal characteristics of the } \\
\text { individual changed when diagnosed with } \\
\text { infertility and how this affected sexual } \\
\text { functioning. }\end{array}$ & $\begin{array}{l}\text { No differences were found in personal } \\
\text { characteristics after the diagnosis of infertility } \\
\text { in experimental groups; however, higher rates } \\
\text { of stress were reported. Stress connected with } \\
\text { infertility had negative impact on sexual } \\
\text { function; fertile couples had better sexuality } \\
\text { than the two experimental groups. }\end{array}$ \\
\hline $\begin{array}{l}\text { Davari Tanha et al. } \\
(2014)^{19}\end{array}$ & $\begin{array}{l}191 \text { primary and } 129 \text { secondary infertile } \\
\text { women, compared with } 87 \text { fertile women. } \\
\text { Sexual function was investigated. }\end{array}$ & $\begin{array}{l}\text { Sexual function was deprived in infertile } \\
\text { women; secondary infertility was linked } \\
\text { with worst results. }\end{array}$ \\
\hline \begin{tabular}{|l} 
Jamali et al. \\
$(2014)^{34}$
\end{tabular} & $\begin{array}{l}100 \text { infertile and } 100 \text { fertile women. } \\
\text { Sexual function was evaluated. }\end{array}$ & $\begin{array}{l}\text { Sexual function was better in the group } \\
\text { of infertile women. }\end{array}$ \\
\hline $\begin{array}{l}\text { Ozkan et al. } \\
(2015)^{20}\end{array}$ & $\begin{array}{l}56 \text { infertile and } 48 \text { fertile men. Sexual function } \\
\text { and rates of depression were researched. }\end{array}$ & Infertile men had impaired sexual function. \\
\hline $\begin{array}{l}\text { Direkvand } \\
\text { Moghadam et al. } \\
(2015)^{21}\end{array}$ & $\begin{array}{l}384 \text { women divided into fertile and infertile } \\
\text { groups. Sexual function was studied. }\end{array}$ & $\begin{array}{l}\text { Sexual function was impaired in the group } \\
\text { of infertile women. }\end{array}$ \\
\hline Song et al. $(2016)^{22}$ & $\begin{array}{l}236 \text { infertile men. Rate of stress was measured } \\
\text { according to the fertile and infertile days } \\
\text { of their partners. }\end{array}$ & $\begin{array}{l}\text { Infertility diagnosis of the couple negatively } \\
\text { affected male sexual function. }\end{array}$ \\
\hline $\begin{array}{l}\text { Czyżkowska et al. } \\
(2016)^{23}\end{array}$ & $\begin{array}{l}50 \text { infertile and } 50 \text { fertile women. } \\
\text { Sexual function and sexual satisfaction were } \\
\text { investigated. }\end{array}$ & $\begin{array}{l}\text { Impaired sexual function was found } \\
\text { in infertile women. }\end{array}$ \\
\hline $\begin{array}{l}\text { Emec et al. } \\
(2017)^{24}\end{array}$ & $\begin{array}{l}137 \text { infertile and } 142 \text { fertile women. } \\
\text { Sexual function was estimated. }\end{array}$ & $\begin{array}{l}\text { There were no significant differences } \\
\text { in sexual function between the groups } \\
\text { of fertile and infertile women. }\end{array}$ \\
\hline
\end{tabular}


Table 4. Research findings regarding the incidence of sexual dysfunctions in infertile couples

\begin{tabular}{|c|c|c|}
\hline Authors (year) & Description of methodology & Summary of results \\
\hline $\begin{array}{l}\text { Pakpour et al. } \\
(2012)^{25}\end{array}$ & $\begin{array}{l}410 \text { and } 194 \text { women with primary } \\
\text { and secondary infertility, respectively. } \\
\text { The incidence of sexual dysfunctions was } \\
\text { estimated. }\end{array}$ & $\begin{array}{l}56 \% \text { of all infertile women had some form } \\
\text { of sexual dysfunction. }\end{array}$ \\
\hline $\begin{array}{l}\text { Aggarwal et al. } \\
(2013)^{26}\end{array}$ & $\begin{array}{l}267 \text { infertile and } 233 \text { fertile women. } \\
\text { The incidence of sexual dysfunctions was } \\
\text { compared between the groups. }\end{array}$ & $\begin{array}{l}63.67 \% \text { of infertile women reported some } \\
\text { form of sexual dysfunction in comparison to } \\
46.35 \% \text { of fertile women. }\end{array}$ \\
\hline $\begin{array}{l}\text { Bayar et al. } \\
(2014)^{27}\end{array}$ & $\begin{array}{l}50 \text { couples with primary infertility. } \\
\text { Rate of sexual dysfunctions was evaluated } \\
\text { at the beginning and } 3 \text { months after initiation } \\
\text { of infertility treatment. }\end{array}$ & $\begin{array}{l}\text { At the beginning of infertility treatment, } \\
60 \% \text { of women and } 34 \% \text { of men had some } \\
\text { form of sexual dysfunction. After } 3 \text { months } \\
\text { of fertility treatment, } 72 \% \text { of women and } 48 \% \\
\text { of men suffered from sexual dysfunctions. }\end{array}$ \\
\hline $\begin{array}{l}\text { Bakhtiari et al. } \\
(2015)^{28}\end{array}$ & $\begin{array}{l}236 \text { infertile men. The prevalence of sexual } \\
\text { dysfunctions was estimated. }\end{array}$ & $\begin{array}{l}58 \% \text { of infertile men suffered from sexual } \\
\text { dysfunctions. }\end{array}$ \\
\hline $\begin{array}{l}\text { Czyżkowska et al. } \\
(2016)^{23}\end{array}$ & $\begin{array}{l}50 \text { infertile and } 50 \text { fertile women. } \\
\text { The incidence of sexual dysfunctions was } \\
\text { determined. }\end{array}$ & $\begin{array}{l}90 \% \text { of infertile women suffered from sexual } \\
\text { dysfunctions in comparison to } 26 \% \text { of fertile } \\
\text { women. }\end{array}$ \\
\hline $\begin{array}{l}\text { Bakhtiari et al. } \\
(2016)^{28}\end{array}$ & $\begin{array}{l}236 \text { infertile women. The incidence of sexual } \\
\text { dysfunctions was estimated. }\end{array}$ & $\begin{array}{l}55.5 \% \text { of infertile women reported some } \\
\text { form of sexual dysfunction. }\end{array}$ \\
\hline $\begin{array}{l}\text { Kucur Suna et al. } \\
(2016)^{29}\end{array}$ & $\begin{array}{l}142 \text { infertile women were divided into three } \\
\text { groups. Group A consisted of } 30 \text { women } \\
\text { diagnosed with infertility. Group B consisted } \\
\text { of } 31 \text { women, with their men diagnosed as } \\
\text { infertile. Group C consisted of } 81 \text { women } \\
\text { with idiopathic infertility. The incidence of } \\
\text { sexual dysfunctions and depression was } \\
\text { investigated. }\end{array}$ & $\begin{array}{l}43.3 \% \text { of group A women, } 54.8 \% \text { of group B } \\
\text { women and } 51.9 \% \text { of group C women suffered } \\
\text { from some form of sexual dysfunction. }\end{array}$ \\
\hline $\begin{array}{l}\text { Emec et al. } \\
(2017)^{24}\end{array}$ & $\begin{array}{l}137 \text { infertile and } 142 \text { fertile women. } \\
\text { The incidence of sexual dysfunctions was } \\
\text { assessed. }\end{array}$ & $\begin{array}{l}78.8 \% \text { of infertile women reported some form } \\
\text { of sexual dysfunction in comparison to } 76.8 \% \\
\text { of fertile women. }\end{array}$ \\
\hline
\end{tabular}

\section{Results}

For the first research question, eight studies were found ${ }^{18-24}$. The samples of the studies were different, from the smallest study with 100 to the largest with 407 individuals. Only one study researched the influence of infertility on couples, while the others were focused on women only (4 studies) or men (3 studies). Research findings are summarized in Table 3.

For analysis of the incidence of sexual dysfunctions in infertile couples, eight studies matched the inclusion criteria ${ }^{23-29}$. The study samples varied from 100 to 604 individuals. One study included both partners, whereas six studies assessed the incidence of sexual dysfunctions in women and one study in men. The results are illustrated in Table 4.
Satisfaction with sexuality was investigated by nine studies $^{18,20-21,23-26,30-31}$. The largest study sample consisted of 497 individuals, whereas the smallest included 100 individuals. Three studies were performed among infertile couples, one among infertile men, and five among infertile women. The results of the studies are summarized in Table 5.

\section{Discussion}

Even though infertility is considered a problem of both partners and diagnostics is always performed on couples, in the previous five years there were only a few studies that investigated sexual function in couples $^{27,30-31}$. However, when also considering the results 
Table 5. Research findings regarding sexual satisfaction of infertile couples

\begin{tabular}{|c|c|c|}
\hline Authors (year) & Description of methodology & Summary of results \\
\hline $\begin{array}{l}\text { Pakpour et al. } \\
(2012)^{25}\end{array}$ & $\begin{array}{l}410 \text { and } 194 \text { women with primary and secondary } \\
\text { infertility, respectively. Estimation of sexual satisfaction. }\end{array}$ & $\begin{array}{l}\text { Both groups expressed low levels } \\
\text { of sexual satisfaction. }\end{array}$ \\
\hline $\begin{array}{l}\text { Marci et al. } \\
(2012)^{18}\end{array}$ & $\begin{array}{l}30 \text { couples diagnosed with infertility in the previous } 2 \\
\text { months, } 30 \text { primary infertility couples in the process of } \\
\text { infertility treatment, and } 52 \text { fertile couples. The research } \\
\text { aimed to define sexual satisfaction of all three groups. }\end{array}$ & $\begin{array}{l}\text { Infertile couples were less satisfied } \\
\text { with sexuality. }\end{array}$ \\
\hline $\begin{array}{l}\text { Aggarwal et al. } \\
(2013)^{26}\end{array}$ & $\begin{array}{l}267 \text { infertile and } 233 \text { fertile women. Sexual satisfaction } \\
\text { was evaluated. }\end{array}$ & $\begin{array}{l}35 \% \text { of infertile and } 38 \% \text { of fertile } \\
\text { women were sexually unsatisfied. }\end{array}$ \\
\hline $\begin{array}{l}\text { Ozkan et al. } \\
(2015)^{20}\end{array}$ & $\begin{array}{l}56 \text { infertile and } 48 \text { fertile men. Effects of infertility were } \\
\text { measured. }\end{array}$ & $\begin{array}{l}\text { Infertile men were less sexually } \\
\text { satisfied. }\end{array}$ \\
\hline $\begin{array}{l}\text { Direkvand } \\
\text { Moghadam et al. } \\
(2015)^{21}\end{array}$ & $\begin{array}{l}384 \text { women were divided into fertile and infertile groups. } \\
\text { Sexual satisfaction was estimated. }\end{array}$ & $\begin{array}{l}\text { Infertile women were less sexually } \\
\text { satisfied. }\end{array}$ \\
\hline $\begin{array}{l}\text { Masoumi et al. } \\
(2016)^{30}\end{array}$ & $\begin{array}{l}125 \text { couples that had been infertile for more than } 5 \text { years } \\
\text { and } 125 \text { fertile couples. Quality of life, sexual and marital } \\
\text { satisfaction were measured. }\end{array}$ & $\begin{array}{l}\text { Infertile couples were more } \\
\text { sexually satisfied. }\end{array}$ \\
\hline $\begin{array}{l}\text { Yangin et al. } \\
(2016)^{31}\end{array}$ & $\begin{array}{l}102 \text { infertile couples. The rate of sexual satisfaction was } \\
\text { also investigated. }\end{array}$ & $\begin{array}{l}37.3 \% \text { of women and } 33.3 \% \\
\text { of men were sexually unsatisfied. }\end{array}$ \\
\hline $\begin{array}{l}\text { Czyżkowska et al. } \\
(2016)^{23}\end{array}$ & 50 infertile and 50 fertile women. & $\begin{array}{l}\text { Findings revealed significantly } \\
\text { lower levels of sexual satisfaction } \\
\text { in infertile women. }\end{array}$ \\
\hline $\begin{array}{l}\text { Emec et al. } \\
(2017)^{24}\end{array}$ & $\begin{array}{l}137 \text { infertile and } 142 \text { fertile women. Sexual satisfaction } \\
\text { was measured. }\end{array}$ & $\begin{array}{l}\text { Infertile women were less } \\
\text { (but not significantly) satisfied } \\
\text { with their sexuality. }\end{array}$ \\
\hline
\end{tabular}

of the studies that dealt with the effects of infertility on sexual function in women and separately in men, it can be concluded that infertility negatively influences couple's sexuality. This was confirmed by a study published in $2012^{18}$. The same study revealed that the consequences of infertility on sexuality were worse in women than in men.

Most of the studies evaluating women's sexuality used the standardized Female Sexual Function Index (FSFI); however, one study ${ }^{23}$ used the Mell-Krat scale. This might affect comparison of the studies, although the findings did reflect the results of other authors. The majority of studies confirmed that infertile women had problems with sexual function; in a study published in 2014, which used the FSFI to evaluate it, sexual function of infertile women was estimated to $25.7 \pm 4.6$, while in fertile women it was $32 \pm 1.1^{19}$. One year later, another study ${ }^{21}$ confirmed these findings. Their results revealed that infertile women scored lower in all six parameters of the FSFI scale. Similar results were also recorded in a study using the Mell-Krat scale $^{23}$, in which infertile women achieved a mean of $46.68 \pm 7.15$ points versus $56 \pm 8.31$ points in fertile women. In contrast, one study ${ }^{32}$ found better sexual function in infertile women; however, the difference on the FSFI was very small (infertile women achieved a mean of $24.83 \pm 4.72$ and fertile ones $23.85 \pm 4.34$ points). A study published in $2017^{24}$ did not confirm the negative impact of infertility on sexual function; infertile and fertile women achieved $17.49 \pm 7.20$ and $17.86 \pm 6.41$ points on the FSFI, respectively. The last two studies were those with smaller samples than the others had; however, more studies in the future would provide a more reliable insight into the impact of infertility on sexual function.

One highly significant finding was highlighted by a study comparing secondary and primary infertility women ${ }^{19}$, which showed that sexual function was most seriously impaired in women with secondary infertility. This should have important implications, i.e. women with such diagnoses would need even more support and help. Lower levels of sexual function among these 
women are also inferred from older studies ${ }^{25}$. Additional studies investigating secondary infertility should also take into consideration marital satisfaction and other life circumstances (levels of anxiety, depression, and stress).

There are fewer studies investigating the effect of infertility on men. The majority of studies performed on men used the International Index of Erectile Function as an instrument to estimate male sexual function. A study published in $2015^{20}$ identified lower sexual function in infertile men in all parameters except for erectile function, in which there was no significant difference. A year later, a study by Song et al. ${ }^{22}$ confirmed these findings, pointing out that sexual function of men is more deprived in the fertile period of their partner's cycle, which can be attributed to sexual anxiety $^{32}$. However, it should be noted that they used the visual analog scale as a research tool, which has not been validated for measuring sexual function. Nevertheless, their study found erectile dysfunction to be the most common sexual dysfunction (50.9\%), whereas another study ${ }^{28}$ concluded that premature ejaculation was most common. This confirms the previous results of a literature review ${ }^{16}$.

However, studies confirm that more women than men have sexual dysfunctions when diagnosed with infertility ${ }^{27,29}$ because infertility treatment also causes stress in partners, which can result in sexual dysfunctions ${ }^{27}$. Since marital problems are inter-related, it can also be assumed that sexual dysfunction of one partner can provoke sexual dysfunctions in the other. This might explain the high rates of sexual dysfunctions in women. The study by Kucur Suna et al. ${ }^{29}$, for example, confirmed that sexual dysfunctions affected mostly women when their partner was diagnosed as infertile.

Dysfunctions can be defined as problems only if they are disturbing to partners ${ }^{8}$. Therefore, we were also interested in estimating sexual satisfaction of infertile couples. Most studies confirm that sexual satisfaction among infertile couples is lower than among

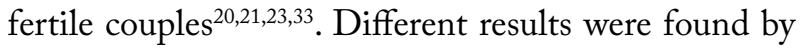
other studies ${ }^{24,26,30}$ in which researchers did not find any statistically significant differences. More studies would be needed in order to define whether the levels of sexual satisfaction are lower in the case of infertility.

The studies included in the analysis suffered from some limitations. Some of them had very small samples $^{20,23,27}$, others ${ }^{22,25,28,30,31}$ did not have control group of fertile individuals, and not all studies used the same research tool to evaluate the impact of infertility on sexual issues. The majority of the research was performed in Turkey ${ }^{15,31}, \operatorname{Iran}^{20,30}$, and India ${ }^{26}$, thus the specifics of the culture could have affected the results. Studies of infertile men remain very rare and provide a limited insight into their dealing with the issue; therefore, such studies should be encouraged in the future.

For future research, we would recommend multicultural samples of couples, with a control group. Since infertility also affects other parameters of partnership (not only sexuality), other measures should also be considered (marital satisfaction, intimacy, etc.) when interpreting sexual satisfaction.

\section{Conclusion}

The majority of studies confirmed the negative effects of infertility on couples' sexuality. This impact was found to be most pronounced in women with secondary infertility. The results also imply that infertility treatment may increase the risk of sexual dysfunctions. This gives certain indices for clinical improvements of infertility management.

Couples who go through the process of infertility treatment are never evaluated for sexual dysfunctions ${ }^{11}$, but they should be, and they should also be offered help in case of diagnosis of sexual dysfunction ${ }^{35-37}$. In the case of unwilling childlessness, sexual therapy should be offered to clients, so that the quality of sexuality is at least the same as before the infertility treatment ${ }^{16}$.

\section{References}

1. Knez J, Vlaisavljević V. Ženska neplodnost. In: Takač I, Geršak $\mathrm{K}$, eds. Ginekologija in perinatologija. $1^{\text {st }}$ edn. Maribor: Medicinska fakulteta; 2016. p. 170-9. (in Slovene)

2. Vlaisavljević V. Neplodnost. In: Borko E, Takač I, eds. Ginekologija. $2^{\text {nd }}$ edn. Maribor: Visoka zdravstvena šola; 2006. p. 307-36. (in Slovene)

3. Zegers Hochschild F, Adamson GD, Mouzon J Ishihara O, Mansour R, Nygren K, Sullivan E, Vanderpoel S; International Committee for Monitoring Assisted Reproductive Technology; World Health Organization, International Committee for Monitoring Assisted Reproductive Technology (ICMART) and the World Health Organization (WHO) Revised Glossary of ART Terminology. Fertil Steril. 2009;92(5):1520-4. DOI: 10.1016/j.fertnstert.2009.09.009.

4. Mascarenhas MN, Flaxman SR, Boerma T, Vanderpoel S, Stevens GA. National, regional, and global trends in infertility 
prevalence since 1990: a systematic analysis of 277 health surveys.PLoS Med.2012;9(12):e1001356. DOI: 10.1371/journal. pmed.1001356.

5. Vogler A. Obravnava neplodnega para. In: Vrtačnik Bokal E, Jančar N, eds. Sodobne oblike zdravljenja neplodnosti/IV spominski sestanek akad. prof. dr. Lidije Andolšek-Jeras. Ljubljana: Slovensko društvo za reproduktivno medicine, 2007; p. 104. (in Slovene) Available from: https://issuu.com/reprodukcija/ docs/as-iv-neplodnost-2007.

6. Zorn B. Moška neplodnost. In: Takač I, Geršak K, eds. Ginekologija in perinatologija. $1^{\text {st }}$ edn. Maribor: Medicinska fakulteta. 2016; p. 206-16. (in Slovene)

7. Raheem A, Ralph D. Male infertility: causes and investigations. Trends Urol Men's Health. 2011;2(5):8-11. DOI: http:// doi.org./10.1002/tre.216.

8. Daniluk JC, Koert E, Breckon E. Sexuality and infertility. In: Binik YM, Hall KSK, eds. Principles and Practice of Sex Therapy. $5^{\text {th }}$ edn. New York: The Guilford Press, 2014; p. 419-36.

9. Piva I, Lo Monte G, Graziano A, Marci R. A literature review on the relationship between infertility and sexual dysfunction: does fun end with baby making? Eur J Contracept Reprod Health Care. 2014;19(4):231-7. DOI: 10.3109/13625187. 2014.919379.

10. Braverman AM. Psychosocial aspect of infertility: sexual dysfunction. Int Congr Ser. 2004;1266:270-6. doi: 10.1016/j.ics. 2004.01.085.

11. Globevnik Velikonja V. Psihološko svetovanje ob neplodnosti. In: Vrtačnik Bokal E, Jančar N, eds. Sodobne oblike zdravljenja neplodnosti/IV spominski sestanek akad. prof. dr. Lidije Andolšek-Jeras. Ljubljana: Slovensko društvo za reproduktivno medicine, 2007. p. 102-7. (in Slovene) Available from: https:// issuu.com/reprodukcija/docs/as-iv-neplodnost-2007.

12. Onat G, Beji NK. Marital relationship and quality of life among couples with infertility. Sex Disabil. 2012;30(1):39-52. DOI: $10.1007 / \mathrm{s} 11195-011-9233-5$.

13. American Psychiatric Association. The Diagnostic and Statistical Manual of Mental Disorders. $5^{\text {th }}$ edn. Washington, DC: American Psychiatric Association; 2013.

14. Nelson CJ, Shindel AW, Naughton CK, Ohebshalom M, Mulhall JP. Prevalence and predictors of sexual problems, relationship stress, and depression in female partners of infertile couples. J Sex Med. 2008;5(8):1907-14. DOI: 10.1111/j.17436109.2008.00880.x.

15. Oskay UY, Beji NK, Serdaroglu H. The issue of infertility and sexual function in Turkish women. Sex Disabil. 2010;28(2): 71-9. doi: 10.1007/s11195-010-9158-4.

16. Wischmann TH. Sexual disorders in infertile couples. J Sex Med. 2010;7(5):1868-76. DOI: 10.1111/j.1743-6109.2010. 01717.x.

17. Eccles M, Mason J. How to develop cost-conscious guidelines. Health Technol Assess. 2001;5(16):1-69.

18. Marci R, Graziano A, Piva I, Lo Monte G, Soave I, Giugliano E, Mazzoni S, Capucci R, Carbonara M, Caracciolo S,
Patella A. Procreative sex in infertile couples: the decay of pleasure? BioMed Central. 2012;10:1-7. DOI: 10.1186/14777525-10-140.

19. Davari Tanha F, Mohseni M, Ghajarzadeh M. Sexual function in women with primary and secondary infertility in comparison with controls. Int J Impot Res. 2014;26(4):132-4. DOI: 10.1038/ijir.2013.51.

20. Ozkan B, Orhan E, Aktas N, Coskuner ER. Depression and sexual dysfunction in Turkish men diagnosed with infertility. Urology. 2015;85(6):1389-93. DOI: 10.1016/j.urology.2015. 03.005 .

21. Direkvand Moghadam A, Delpisheh A, Direkvand Moghadam A. Effect of infertility on sexual function: a cross-sectional study. J Clin Diagn Res. 2015;9(5):1-3. DOI: 10.7860/ JCDR/2015/11148.5934.

22. Song SH, Kim DS, Yoon TK, Hong JY, Shim SH. Sexual function and stress level of male partners of infertile couples during the fertile period. BJU Int. 2016;117(1):173-6. DOI: 10.1111/ bju.13201.

23. Czyżkowska A, Awruk K, Janowski K. Sexual satisfaction and sexual reactivity in infertile women: the contribution of the $\mathrm{dy}$ adic functioning and clinical variables. Int J Fertil Steril. 2016;9(4):465-76.

24. Emec ZA, Apay SE, Ozorhan EY. Determination and comparison of sexual dysfunctions of women with and without infertility problems. Sex Disabil. 2017;35(1):59-72. DOI: 10.1007/s11195-016-9471-7.

25. Pakpour AH, Yekaninejad MS, Zeidi IM, Burri A. Prevalence and risk factors of the female sexual dysfunction in a sample of infertile Iranian women. Arch Gynecol Obstet. 2012;286 (6):1589-96. DOI: 10.1007/s00404-012-2489-x.

26. Aggarwal RS, Mishra VV, Jasani AF. Incidence and prevalence of sexual dysfunction in infertile females. Middle East Fertil Soc J. 2013;18(3):187-90. DOI: 10.1016/j.mefs.2013.02.003.

27. Bayar U, Basaran M, Atasoy N, Kokturk F, Arikan II, Barut A, Harma M, Harma M. Sexual dysfunction in infertile couples: evaluation and treatment of infertility. J Pak Med Assoc. 2014;64(2):138-45.

28. Bakhtiari A, Basirat Z, Aghajani Mir M. Sexual dysfunction in men seeking infertility treatment: the prevalence and associations. Caspian J Reprod Med. 2015;1(3):2-6.

29. Kucur Suna K, Ilay G, Aysenur A, Kerem Han G, Eda Ulku U, Pasa U, Fatma C. Effects of infertility etiology and depression on female sexual function. J Sex Marital Ther. 2016;42(1): 27-35. DOI: 10.1080/0092623X.2015.1010673.

30. Masoumi SZ, Garousian M, Khani S, Oliaei SR, Shayan A. Comparison of quality of life, sexual satisfaction and marital satisfaction between fertile and infertile couples. Int J Fertil Steril. 2016;10(3):290-6. DOI: 10.22074/ijfs.2016.5045

31. Yangin H, Kukulu K, Gulşen S, Aktaş M, Sever B. A survey on the correlation between sexual satisfaction and depressive symptoms during infertility. Health Care Women Int. 2016; 37(10):1082-95. DOI: 10.1080/07399332.2015.1107067. 
32. Peterson BD, Newton CR, Feingold T. Anxiety and sexual stress in men and women undergoing infertility treatment. Fertil Steril. 2007;88(4):911-4.DOI: 10.1016/j.fertnstert.2006. 12.023.

33. Yeoh SH, Razali R, Sidi H, Razi ZR, Midin M, Nik Jaafar NR, Das $S$. The relationship between sexual functioning among couples undergoing infertility treatment: a pair of perfect gloves. Compr Psychiatry. 2014;55(Suppl 1):S1-S6. DOI: 10.1016/j.comppsych.2012.09.002.

34. Jamali S, Rasekh JA, Javadpour S. Sexual function in fertile and infertile women referring to the Jahrom Infertility in 2011. Jundishapur J Chronic Dis Care. 2014;3(1):11-20.
35. Zavoreo I, Gržinčić T, Preksavec M, Madžar T, Bašić Kes V. Sexual dysfunction and incidence of depression in multiple sclerosis patients. Acta Clin Croat. 2016;55:402-6. DOI: 10.20471/acc.2016.55.03.08.

36. Jelavić MM, Krstačić G, Perenčević A, Pintarić H. Sexual activity in patients with cardiac diseases. Acta Clin Croat. 2018; 57:141-8. DOI: 10.20471/acc.2018.57.01.18.

37. Starc A, Jukić T, Poljšak B, Dahmane R. Female sexual function and dysfunction: a cross-national prevalence study in Slovenia. Acta Clin Croat. 2018;57:52-60. DOI: 10.20471/acc.2018. 57.01.06.

Sažetak

\title{
NEPLODNOST I SEKSUALNI POREMEĆAJI: SUSTAVNI PREGLED LITERATURE
}

\author{
A. Starc, M. Trampuš, D. Pavan Jukic, C. Rotim, T. Jukić i A. Polona Mivšek
}

Ova studija je imala za cilj istražiti utjecaj neplodnosti i njezinog liječenja na seksualnost para. Izvršena je sustavna analiza literature s naglaskom na seksualnu disfunkciju žena i muškaraca zbog neplodnosti. Metoda je bila opisna uz primjenu meta-sinteze znanstvenih istraživanja objavljenih između 2012. i 2017. godine na engleskom jeziku. Pretraživanje odgovarajućih studija provedeno je u bazama podataka Medline, CINAHL, PubMed i ScienceDirect koristeći sljedeće ključne riječi: neplodnost, seksualne disfunkcije, par. Može se zaključiti da neplodnost negativno utječe na seksualnost neplodnog para, što dodatno dokazuje visok postotak seksualnih disfunkcija (43\%-90\% među ženama i 48\%-58\% među muškarcima). Parovi iskazuju manje zadovoljstvo u seksualnom odnosu. Budući da su slabije zadovoljstvo i disfunkcije usko povezane s neplodnošću i njenim liječenjem, parovi bi mogli imati koristi od seksualne terapije i psihološke potpore tijekom procesa liječenja neplodnosti. Daljnja bi se istraživanja trebala usredotočiti na evaluaciju različitih psiholoških intervencija koje bi se bavile seksualnošću kod parova kad im se dijagnosticira i liječi neplodnost.

Ključne riječi: Neplodnost; Seksualnost; Erektilna disfunkcija; Seksualne disfunkcije, psihološke 